\title{
Promoting Positive Youth Development: Youth Participation in International Youth Exchange Program
}

Fazulia Zulkifli, Mohd Mursyid Arshad, Ismi Arif Ismail, Haslinda Abdullah, Mohd Yusof Zulkefli

To Link this Article: http://dx.doi.org/10.6007/IJARBSS/v11-i19/11715

DOI:10.6007/IJARBSS/v11-i19/11715

Received: 06 October 2021, Revised: 30 October 2021, Accepted: 20 November 2021

Published Online: 12 December 2021

In-Text Citation: (Zulkifli et al., 2021)

To Cite this Article: Zulkifli, F., Arshad, M. M., Ismail, I. A., Abdullah, H., \& Zulkefli, M. Y. (2021). Promoting Positive Youth Development: Youth Participation in International Youth Exchange Program. International Journal of Academic Research in Business and Social Sciences, 11(19), 26-43.

Copyright: (C) 2021 The Author(s)

Published by Human Resource Management Academic Research Society (www.hrmars.com)

This article is published under the Creative Commons Attribution (CC BY 4.0) license. Anyone may reproduce, distribute, translate and create derivative works of this article (for both commercial and non-commercial purposes), subject to full attribution to the original publication and authors. The full terms of this license may be seen

at: http://creativecommons.org/licences/by/4.0/legalcode

Special Issue Title: Youth and Community Wellness, 2021, Pg. 26 - 43

Full Terms \& Conditions of access and use can be found at http://hrmars.com/index.php/pages/detail/publication-ethics 


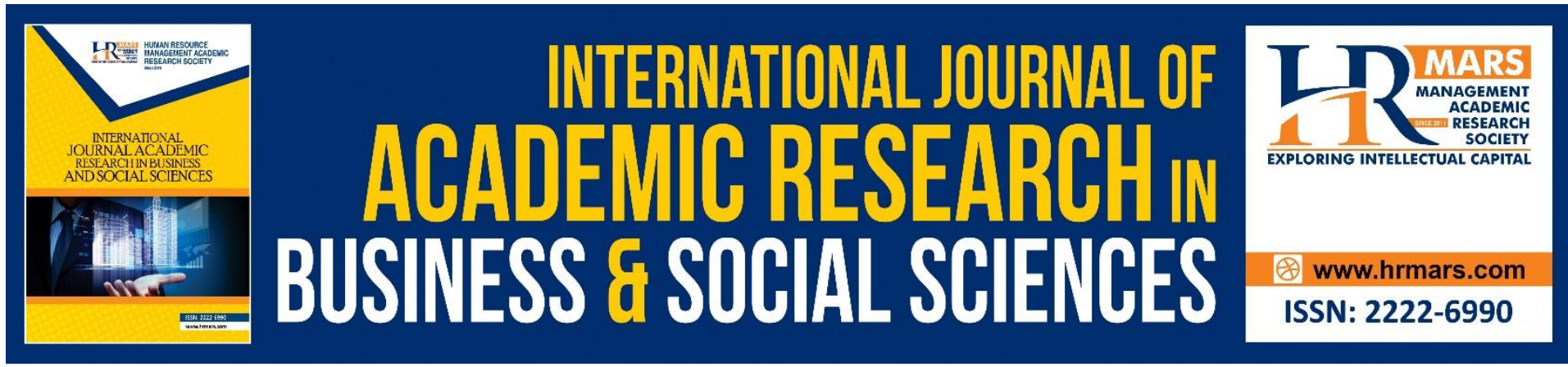

\title{
Promoting Positive Youth Development: Youth Participation in International Youth Exchange Program
}

\author{
Fazulia Zulkifli², Mohd Mursyid Arshad ${ }^{1,2}$, Ismi Arif Ismail ${ }^{1,2}$, \\ Haslinda Abdullah ${ }^{1,2}$, Mohd Yusof Zulkefli ${ }^{3}$ \\ ${ }^{1}$ Institute for Social Science Studies, Putra Infoport, Universiti Putra Malaysia, 43400 UPM \\ Serdang, Selangor, Malaysia, ${ }^{2}$ Faculty of Educational Studies, Universiti Putra Malaysia, \\ 43400, Serdang, Selangor, Malaysia, ${ }^{3}$ Universiti Tunku Abdul Rahman (UTAR) \\ Corresponding Author: m_mursyid@upm.edu.my
}

\begin{abstract}
Malaysian youth are a significant group in steering and shaping Malaysia's future. Consequently, the government introduced many approaches to enhance and expand the potential of the youth. The youth development approach is founded on believing that young people thrive when developmentally supported across all community sectors. Youth development is best promoted through activities and experiences that help youth develop social, ethical, emotional, physical, and cognitive domains. Most youth development approaches can be promoted in Malaysia through the international youth exchange program and a few other programs such as Perdana Fellows Program, Malaysian Youth Parliament, and Malaysian Youth Consultative Council. The international youth exchange program is the most anticipated program among Malaysian youth. The international youth exchange programs focus on exposing youth to global networking, knowledge, and skills. However, to get involved in any international exchange program, a person (youth) needs to go through the selection process. The selection process is vital in order to select a competent youth. Therefore, it is reasonable to expect that participating in organised and structured programs will positively impact the participating youth. Moreover, Positive Youth Development (PYD) can be achieved by elevating the 5Cs of PYD through the programs. Henceforth, this concept paper will thoroughly explain the competence of the youth and its significance on the PYD through the international youth exchange (IYEX) program.
\end{abstract}

Keywords: Youth Development, International Youth Exchange Program, Competency, Positive Youth Development

Introduction

Youth Development

Youth development is a strategic idea that focuses on activities for whole communities to assist all youth to thrive. In other words, when young people are supported in their growth 
throughout all community sectors, they succeed (Turnnidge et al., 2014). For example, schools, youth-serving groups, faith-based organisations, community government, business, the juvenile justice system, etcetera. It builds on traditional youth service techniques by focusing on long-term, systemic methods for nurturing good features and behaviours in young people by creating an environment that fosters their developmental needs and abilities (Qi et al., 2021).

In general, youth is known as a different component of a country's population. Youth is a vital time and a pivotal point since they are neither children nor adults. In the development stages, youth acquire the behaviours, abilities, values, and social skills necessary to become successful adults (Lopez et al., 2015). Along the way, they acquire a set of personal assets or supports that assist them in confronting the challenges and possibilities that loom (Piers et al., 2018). These assets allow youth to become resilient where they will be able to rebuild from difficulties. It can also be connoted that young people drive their development and their ability to thrive depends significantly on the support and assistance from the people and institutions around them.

Moreover, many prior studies have emphasised the importance of youth development. According to scholars, the most significant way to support youth development is to engage them in activities and experiences that help them develop their social, ethical, emotional, physical, and cognitive domains (Roth \& Brooks-Gunn, 2003). It is confirmed by a study that mentioned that youth require contexts that support their development by exposing them to pleasant experiences, situations, and people and conditions that allow them to build and excellent real-world skills (Lerner et al., 2011). As a result, every community must provide a diverse range of youth activities in positive developmental contexts that assist youth in establishing the attitudes, competencies, values, and social skills necessary to become successful adults.

Many youth development programs offer beneficial experiences that extend youth's viewpoints and involvement, enhance their socialisation and talents. Expanding their exposure to developmental opportunities and supports may influence their development toward healthy (positive) outcomes. This positive youth development is the current perspective whereby it highlights the resources and talents of youth by offering various platforms to thrive. For instance, the United Kingdom (U.K.) Youth Parliament, 4-H Programs, and Erasmus Exchange Programs. Firstly, the United Kingdom Youth Parliament allows 11to 18-year-old to utilise their elected voice to effect social change through meaningful representation and advocacy (Roberts et al., 2016). Over 280 seats for elected MYPs are available in the U.K. Youth Parliament (Members of Youth Parliament). MYPs are often elected in annual youth elections across the U.K. Once a year, all MYPs get together during the Annual Sitting of the U.K. Youth Parliament. They organise events and projects, run campaigns, and influence decision-makers on essential issues to young people once elected.

According to one official source from the U.K. Youth Parliament, MYPs establish a line of knowledge and skills. Communication, public speaking, a better understanding of politics 
and current events, the ability to see things from someone else's point of view, arguing, teamwork, leadership, organisation, and negotiating are just a few examples. Those competencies are the perk of engaging in youth development programs. It helps help young people to develop "competencies that will enable them to grow, develop their skills and become healthy, responsible, and caring youth and adults" (Networks for Youth Development, 1998). Second is the 4-H Programs, America's top youth development organisation, another example of a youth development program. 4-H Programs provide hands-on learning opportunities for young people that delivers by the Cooperative Extension-a network of more than 100 public universities around the country. In $4-\mathrm{H}$, children and teenagers engage in various hands-on activities within their growing-up term. They also complete hands-on projects in health, science, agriculture, and civic engagement in a constructive environment. Adult mentors acted as a guide and encouraged them to take on proactive leadership roles. In other words, they get a variety of experiences under the concept of learning by doing. It is an example of the term; "development is a process, not a goal". The significance of 4-H is described by a study whereby it stated that 4- $\mathrm{H}$ has the goal of positive youth personal development and seeks to help youth develop life skills relevant to their lives (Enfield, 2001).

While, in Europe, there is an Erasmus Exchange Program to support education, training, youth, and sport. The program emphasises social inclusion, environmental and digital transformations. The program also encourages young people to participate in democratic life. Studying abroad is an essential aspect of Erasmus and has been demonstrated to improve career opportunities in the future. It is also an opportunity to develop language skills, build self-confidence and independence, and learn about a new culture among youth participants. Therefore, a foreign study experience has a good impact on student exchange programs. Furthermore, it demonstrates that student exchange programs like Erasmus have a positive impact on long-term stability. According to a study, the benefits of an academic experience abroad can be summarised in the form of seven significant characteristics. The personal level of student exchange program participants, for example, can boost their employability.

The programs also act as a platform for learning new languages and refining existing ones. Academic exchange program participants also improve their self-sufficiency and develop intercultural abilities (Kabanbayeva et al., 2019). For example, the Erasmus Programme is seen as a learning platform in which young students get significant experience and training in the realities of life in an increasingly connected society (Tsoukalas, 2019). Furthermore, the student's self-perception, social representations, and social identity are transformed due to the overwhelming experiences, both emotionally and cognitively. These programs explain that people continue to evolve throughout their lives. As a result, fostering youth development is a long-term, overarching goal rather than a short-term goal. A study summarised this feature by stating that development seeks to allow a person to continue to develop (Arshad et al., 2021). In this light, the identification of goals becomes more difficult. Developmental goals identify demands for growth rather than defining specific and measurable behaviours (Zulkefli \& Rabi, Exploring the Usage of Computer-Mediated 
Communication in Assisting Individual with Autism Spectrum Disorder to Communicate, 2021). Therefore, in this sense, development can be seen as a progression process, opposed to attainment, which is the key.

\section{Youth Development in Malaysia}

Beginning in the late 1980s, Malaysian adolescents displayed a significant shift in their lifestyles and thought patterns. They are the first generation in Malaysian history to grow up with computers, music downloads, instant messaging, and cell phones. Young people may be more tolerant of internationalism because of the 'open sky' concept, information and media liberalisation. However, youth may experience identity uncertainty without adult guidance and awareness, feeling connected and alienated. Notwithstanding, Malaysian youth have demands according to their age, location, and circumstances (Hamzah, 2005).

The competitive global environment has demanded creativity, futurism, and always being on track with the latest technological developments. This social transformation has hugely influenced the thinking and lifestyle of today's youth generation. Thus, the formulation of strategies and efforts for the country's youth development is a complex undertaking because the country's youth are diverse in terms of socio-cultural and socio-economic status. The current Malaysian Youth Policy (MYP) has categorised youth in Malaysia into eight (8) Target Groups. This youth classification is expected to make it easier for stakeholders to establish particular programs or initiatives based on more strategic youth development planning and implementation (Ministry of Youth and Sports, 2015).

Malaysia's youth development is guided by the Malaysian Youth Policy (MYP) 2015, which intends to reinforce and highlight youth human capital as a future catalyst of the country's strategic growth (Ministry of Youth and Sports, 2015). Therefore, the government's commitment to implementing MYP's goals is based on three Policy Thrusts: Positive Youth Development (PYD), From Youth to Youth, and Youth as a National Resource and Asset. Similarly, the 11th Malaysia Plan's youth development agenda for 2016-2020 aims to increase young well-being by preparing them to become charismatic, dynamic, and progressive generations (Economic Planning Unit, 2015).

In order to detail the strategy and steps that need to be taken by the Ministry of Youth and Sports, four strategic thrusts have been worked on considering the latest environmental scenarios and trends. The first is an effort to improve the effectiveness of strategies and initiatives implemented (Ministry of Youth and Sports, 2016). Second, in maximising youths' potential for the country's social well-being, the self and potential of youths need to be strengthened, which leads to the implementation of PYD-based programs. For instance, the Perdana Fellows Program, the Malaysian Youth Parliament, the Malaysian Youth Consultative Council, the IYEX Programs, and youth entrepreneurship.

The Perdana Fellows Program (PFP) is a prominent program that aims to create the next generation of Malaysian leaders across multiple sectors by providing young Malaysians with first-hand experience in topics of national governance. Perdana Fellows are placed under 
the jurisdiction of Ministers of several Ministries as part of this program to assist in the highest level of administration (Youth Development Division, 2016). Upon expiration of the fellowship period, they become the member of the Perdana Fellows Alumni Association. They will continue the tradition of establishing a great network between youth leaders and government, corporate, and NGO leaders. Perdana Fellows is seen as one of the mediums for forming new leadership potentials among youths through mentoring.

Youths can develop skills, form youth leadership, continuation and maintain relationships between youths (protégés) and adults (mentors). It is gleaned by a prior study that examined the potential of mentoring on positive youth development in a youth leadership development program (Arshad et al., 2017). Furthermore, mentoring has opened opportunities for youth leaders to access ecological assets through the communities they join. Finally, it directly develops a network element (connection) in the PYD by forming non partisan leadership and leading social change. In sum, youth development efforts through the mentoring leadership process can increase the positive values of youth. Ideally, (Lerner et al., 2013) have discussed the relationship between PYD with individuals as a development asset associated with mentoring that serves as a positive resource in youth life.

Another youth leadership program in Malaysia is the Malaysian Youth Parliament (PBM) aims to train and produce a line of young leaders who are of calibre and credibility in line with the country's needs in the future. Specifically, the objective of PBM is to improve leadership knowledge and skills among the youth for the continuation of long-term national leadership (Youth Development Division, 2016). PBM can also expose youths to how the legal process is made, understand the country's administrative system, and identify youth trends to adapt to national administrative policies. In addition, the Malaysian Youth parliament highlights debating a proposition in the Parliament and engaging with society at grassroots levels.

Each of the Members of the Youth Parliament represents young people in their local area. PBM allows youth involvement in decision-making. Moreover, it has positively impacted youth capacity building and contribution to the government (Sani \& Saad, 2018). Meanwhile, according to United Nations, the active participation and involvement of youth in society and the practice of democracy is vital in response to efforts to meet needs and assurances that their human rights are recognised and enforced (United Nations, 2012). Researchers and practitioners concur that this involvement offers them the ability to speak on behalf of other youth and do so in an acceptable way and gives them an edge (Faulkner, 2009). Moreover, The World Assembly of Youth, in its report entitled "Youth Participation in Decision-Making", found that youth participation leads to better results and outcomes (World Assembly of Youth, 2015). It suggests that young people should be aware of the opportunities to participate in civic and political rights. Also, they get to contribute to the decision-making process that affects their life and the country.

Besides PFP dan PBM, the IYEX Program is among the primary programs under the Ministry's strategic thrust - Youth Internationalization. The IYEX programs are the initiative 
to foster thriving among adolescents who participate in a program that comprises diverse and challenging activities. Under the Ministry of Youth and Sports, IYEX programs are based on bilateral and multilateral agreements. The governments intended to reinforce cooperation at the regional and global levels among the future generation of young people. Apart from that, the agreement also strengthens and increases international programs for youths to get proper exposure. With more exchange programs, more youth will have the opportunity to experience the positive impacts of the programs (Radhakrishna \& Ingram, 2005).

There are two types of IYEX programs: long-term (52 days) and short-term ( 20 days). Both types of programs involve youth to form a contingent to represent Malaysia to participate in the programs. IYEX programs are not mainly about international mobility but how youth engage in such activities designed by the organisers. Scholars agree that youth participation in various activities is advantageous to their development, particularly in promoting PYD and contributing to society (Agans et al., 2013). The real challenge is youth involvement in diverse natures of activities and the different cultures and backgrounds of other participating youth. It requires youth with diverse academic competencies, general knowledge, good conduct in English, social competencies, effective communication, and others. It would test the ability and resilience of youth to display what they can do and shine in the programs.

\section{Literature Review}

\section{Positive Youth Development (PYD)}

Adolescence is one of the most crucial stages that affect the development of young people and can be defined as a key "turning point" in life. Practitioners and policymakers have tried various approaches for decades to prevent problem behaviour among youth and help youth transition to adulthood. Long-held stereotypes about youth associated it with developmental issues that led to juvenile cases, financial difficulties, and other behaviour problems. It seems impractical to design and execute interventions for each single adolescent behaviour problem. Furthermore, the effectiveness of such "deficit" programs is uncertain (Kim et al., 2016; Lai et al., 2016). However, the perception and situation of youth development have changed to a positive perspective (Lerner, 2002; Lerner, 2004) that highlights holistic development based on their strengths and interests rather than focusing on decreasing the behaviour problems.

Since then, many scholars have been discussing Positive Youth Development (PYD). People may ask a common question; "what is PYD?". According to Bonell et al., 2016, positive youth development (PYD) can be characterised as a youth development practice that connects youth with their environment. For example, people or organisations that present in youth's life. The development process includes identifying youth's strengths before utilising and enhancing them, all in the best manner. The explanation supported by Logwood \& Thomas (2017), whereby stated that youth will go beyond just doing and be emotionally and cognitively engaged by being involved in a project invested in any program. The result may be that they show caring. It means that, by making the most of their potential through diverse opportunities, PYD can contribute to adolescent's present and future well-being. 
PYD is not brand-new among scholars and practitioners. During the past two decades, PYD was one of the main topics discussed in youth development. PYD is another perspective that highlights resources, potentials, and strength in youth (Shek et al., 2019). Likewise, Zhou et al., 2020 added that PYD is a redefined and positive path that emphasises developmental plasticity and potential in youth instead of developmental deficits. Moreover, there are several PYD models proposed by scholars that have been used in different frames. All the models have some agreements that concentrate on the strength and potential of youth, plasticity, and internal developmental assets (such as individual competencies), and external developmental assets (such as environment influence) (Shek et al., 2019). Such models involve Benson's 40 developmental assets (Benson et al., 2007), Lerner's 5Cs and 6Cs models (Lerner, 2006), Social-Emotional Learning, and Catalano's 15 PYD constructs (Catalano et al., 2003). The theories, research, and applications are imperative toward designing holistic youth development programs and ultimately contribute to youth well-being.

Concerning that, scholars also have recognised the need of promoting young people's well-being through successful youth programs in the light of the problems associated with youth development. PYD based programs seek to foster and increase youths' PYD traits and strength. Unlike the deficit model, the PYD concept views youth as "precious assets" rather than "problems". The plasticity emphasised in the PYD paradigm suggests that the developmental system promotes desired outcomes rather than prevents unwanted behaviours (Lerner et al., 2005). Therefore, focusing on providing them with various platforms to highlight their abilities, such as resilience, emotional skills, and moral competence (Shek et al., 2019), can help them cope with developmental problems and sustain healthy functioning. Similarly, Zhou et al., 2020 discovered that the PYD approach would help young people develop their inner strengths to be safeguarded from risky behaviour and prosper. The findings portray that youth development programs need to be worked on by adopting the concept of PYD so that youths can face adversities in life and towards the youth's well-being.

In Malaysia, youth development is based on the PYD approach that recognises the potential and strength of youth. Therefore, it is developed positively and following the potential where the youth are. It is divided into two categories: PYD through 8Cs and the development of youth asset well-being (Ministry of Youth and Sports, 2015). The development of youth asset well-being is measured through a study Malaysian Youth Asset Wellbeing Development (Youth Asset Study) was conducted by a group of researchers from the Institute for Youth Research Malaysia (IYRES) and Universiti Putra Malaysia (UPM) in 2015. The results indicated that the overall score of youth assets was reasonable, with an average of external assets of 61.2 and internal assets of 74.6. The gap between the external and internal assets scores suggest that Malaysian youth have the greater internal strength to deal with the obstacles they experience (Institute for Youth Research Malaysia \& Universiti Putra Malaysia, 2015). Apart from that, it can be concluded that external support or the youth development ecosystem needs to be strengthened to highlight the potential of youth. The achievement of internal assets in the Youth Asset Study is seen as the internal strength of the youth to strengthen their level of well-being, as reported by the Malaysian Youth Development Index 2015 (Rawee, 2016). 
Meanwhile, the $8 \mathrm{Cs}$ goals are created in the context of the Malaysian Youth Policy (MYP) based on the demands of Malaysian youth development. The original PYD framework, widely utilised internationally, aimed at the 5Cs (Lerner et al., 2005). There have been additions to the PYD framework in the context of positive youth development in Malaysia. Considerate, competitive, and contribution are the three additional domains (Institute for Youth Research Malaysia, 2018). Youth development in Malaysia is regarded as based on MYP that is relevant and current with the needs of youth to fulfil the objective of positive youth development (8Cs). Regular monitoring and implementing integrated youth development methods are critical to achieving positive youth development in Malaysia. In 2018, a group of researchers from IYRES performed an 8 Cs Positive Youth Development Study to assess the achievement of eight dimensions (8Cs) of positive youth development in Malaysia. According to the findings of this study, the Contribution domain received the highest score, while the Competence domain received the lowest (Institute for Youth Research Malaysia, 2018).

It shows that Malaysian youths contribute something positive to their family, peers, neighbourhood, and community. On the other part, youths in Malaysia need the training to improve their competence, qualifications, and abilities to carry out tasks properly in various fields such as academic, social, emotional, and vocational.

\section{International Youth Exchange (IYEX) Programs}

In the current and modernised century, making connections and communicating ideas among diverse groups of people, particularly the young, focusing on economic, political, security, socio-cultural, and other activities is one of the defining features of international relations. Many young people participate in various exchange programs, such as scientific stages, conferences, training, and other learning activities. The significance of studying the perspective of youth exchanges is determined by their role in strengthening mutual trust and good neighbourly relations. It also led to the development of the integration process in education, science, technology, and youth development. Besides that, youth exchange programs also provide a new purpose to multilateral cooperation, improved quality of life, and the achievement of other millennium development goals.

The concept of exchange programs is not restricted to science and education. According to (Maximova et al., 2018), there is various programs' diversity. Socio-cultural programs have the primary goals of being acquainted with country life, learning a foreign language, learning about history, traditions, and customs, and refuting ethnic and national prejudices and assumptions. The next category is educational and scientific programs, aimed at receiving formal professional education and conducting scientific research, professional internships, and suitable for undergraduates and young specialists looking to expand their knowledge and gain experience (Fitzsimmons, Flanagan, \& Wang, 2013). Another kind is the initiatives as a part of bilateral and multilateral agreements focusing on youth policy and youth work.

In Malaysia, international exchange programs among young people are part of the internationalisation initiatives under the Ministry of Education and Ministry of Youth and Sports. Most of the exchange programs under the Ministry of Education are education-based 
involving students, teachers, lecturers and staff. At the same time, the exchange programs under the Ministry of Youth and Sports are mainly based on bilateral or multilateral agreements in youth \& sports development. It involves young people who represent the youth associations and individual youth. However, nowadays, there are numerous universities students involved. As for the current paper, we focus on IYEX programs under the Ministry of Youth and Sports.

In order to participate in any exchange program in Malaysia, one must first go through the selection process. It consists of several stages where the assessment is based on the organisers' eligibility requirements and selection criteria of the governing body (Baharun et al., 2011). Then, supported by the previous study, successful applicants must go through the selection camp to participate in exchange programs to represent the university, nation, or country (Universiti Malaysia Sabah, 2021). In other words, it is a necessary formality for applicants to go through to assure that they are eligible to represent Malaysia in an exchange program.

The IYEX program is an example of a youth development program that exposes youth to networking among international young people from various countries. It is because the nature of the IYEX program is to nurture friendships and understand them. The program also aims to broaden the youth's perspective, foster leadership abilities in multiple fields, and enhance the spirit of cooperation for global cooperation. IYEX programs are listed among Ministry's internationalisation strategies, which expose Malaysian youth to global networking, knowledge, and skills. In addition, it serves as a forum for young people to showcase their abilities and potential through various IYEX programs (Ministry of Youth and Sports, 2016).

The Ministry of Youth and Sports collaborates with other ministries and governments on some IYEX programs, including the Cabinet Office of Japan, the Ministry of Gender Equality and Family of the Republic of Korea, the Ministry of Youth and Sports of Brunei Darussalam, and the Ministry of Youth and Sports of Indonesia, to name a few. The Youth Development Division of the National Youth and Sports Department is in charge of all IYEX programs within the Ministry's jurisdiction. These IYEX programs require youth to form a contingent with some committees. Therefore, it ensures that all pre-departure preparations, such as pre-program assignments, cultural presentation, contingent attire, and many more, are well-managed.

Before participation in IYEX programs, all participants passed through a challenging selection process, training, and thorough preparation under the guidance of their leaders. Then, they are screened at different levels to determine their suitability and competencies to represent their country in those programs. The stages include psychometric tests, essay assessment, and selection camp. A psychometric test, essay evaluation, and selection camp are among the phases of assessment. The first screening phase is the psychometric test which The Public Service Department (PSD) prepares and analyses the test. This test covers ten personality traits identified by the Ministry to assess the personality of the youth. The ten attributes are rationale, assertiveness, tolerance, social activity, systematic, compassion, expression of feelings, happiness, calmness, and dependability (Youth Development Division, 
2018). The essay evaluation is the second screening stage, in which a short essay based on the required theme is submitted by online application. Assessors from the Youth Development Division are evaluating the essay based on the guidelines established. This screening is for youth who appear to be qualified based on the information submitted for the application.

The final assessment is the Selection Camp whereby it is for youth who have passed the initial screening. The Selection Camp is a powerful instrument for identifying and selecting the best young people to represent the country in IYEX programs. A group of assessors appointed by the Ministry based on their competency evaluates youth throughout the camp (Zulkefli \& Zulkifli, 2021) on all aspects of the discipline, cooperation, communication, leadership, personality, intellectual, and even talent, either during activities or during break time (Youth Development Division, 2018). The only IYEX program requiring interview participants is The Ship for Southeast Asian and Japanese Youth Program (SSEAYP). As for this program, participants are chosen based on assessments before as well as the interview.

Participating youth are constantly stimulated throughout the programs, primarily by the organisers' variety of interactive activities, such as educational visits, homestay programs, courtesy calls on local governors, discussion groups, volunteer activities, solidarity group activities, and national and cultural presentations. Therefore, participants must act creatively and actively to perform different roles and responsibilities under a limited time frame. At the same time, they must follow a tight schedule, prepare the day-to-day activities that are challenging and highly competitive, and need to enjoy the program. Besides that, each contingent must plan and execute specific projects in home countries, which would benefit the communities after returning to their respective countries. Thus, the activity is called PostProgram Activities (PPA). Somehow, it is a very stressful task as a participant. Therefore, participants must be motivated and competent to let their ideas and skills determine their capabilities, which could portray the good image of their countries.

The IYEX programs are an example of a PYD-based program that aims to empower Malaysian youths in building networks with youths from foreign countries and exposing them to global-class knowledge and skills. Therefore, the combination of the strength and competencies of youth and the ecosystem or context of the program itself could lead to positive development among youth.

\section{Positive Youth Development (PYD) through the International Youth Exchange (IYEX) Programs}

Large numbers of people are allowed to travel to different parts of the world each year. Youth develop new skills, form lasting connections, and gain a fresh perspective of themselves and the people around them through short and long-term exchanges that promote cultural understanding and acceptance. IYEX programs or international education mobility programs are possible to develop young people for a better youth. It is because of the commitment, leadership, and passion towards the programs and youth engagement during the programs that make this program unique. 
There are previous studies that mentioned the positive outcomes of international education mobility. According to Tangen et al. (2017), pre-service teachers who participated in the short-term mobility program said that, despite challenges, their thinking style had changed. They are not just thinking outside the box but also in terms of the big picture. It depicts how successfully the program's sharing of ideas, cultures, and perspectives went. Besides that, the study abroad experience positively impacts global citizenship and selfdevelopment (Gabowski et al., 2017). It is because each participant approaches their study abroad experience in a unique way. Some individuals become more involved in student or community activities.

Likewise, the IYEX programs also gained some positive feedback based on previous studies. Findings from a study about youth exchange programs in SCO countries and their integrative potential indicated that exchange programs could develop educational and sociocultural competencies (for example, practising foreign language and ethnocultural competence) (Maximova et al., 2018). Another well-known exchange program is organised by Rotary Clubs, which has over 100 countries participating. Participants improved on some skills, according to the Rotary Exchange annual report. Participants also noted that they were given a significant speaking position during the program, which improved their communication and idea-sharing abilities. Furthermore, participants stay with host families who guide, teach, and impact the lives of the exchange students (Rotary Clubs, 2018). These experiences provide a lesson that can last a lifetime.

As discussed in the literature, this paper focuses on IYEX programs under the purview of the Ministry of Youth and Sports. IYEX programs are based on the PYD approach in which the participants are youths who succeed in the selection conducted by the Ministry. In other words, youth who participate in IYEX programs are representatives who are qualified to represent Malaysia. It also means that youth are competent enough and acquire talent that can be resources in the programs. In the programs, participating youth must consistently engage in a variety of activities. For example, youth involvement in courtesy calls on head of state/ country and join interactions with local youths, homestay in the countries they visited. They are also engaged in various activities such as discussions on everyday issues, cultural presentations, and volunteer activities. These activities are certainly promoting mutual understanding among them and gaining a lot of valuable experiences to grow as leaders with broad perspectives. Furthermore, using the knowledge and experiences during the program, the participating youth design post-program activity including social contribution activities.

The nature of IYEX programs defines the supportive and empowered environments where the activities provide a diversity of skill-building and horizon-widening opportunities (Roth \& Brooks-Gunn, 2003). For example, in discussion activities, participants engage with facilitators and other foreign participants. Besides improving youth's skills in exchanging views with other participants, discussion activities also enhance youth's ability to present their ideas in public through free-flowing and active exchange of opinions. In other words, as aspiring future leaders, youth must acquire knowledge and manage to discuss the topic with other participants. 
Another aspect of the IYEX program is that participants need to plan and execute voluntary activities and seminars. These activities suit the theme from youth to youth which participants must organise activities for other participants interested in joining them. In this part, participants are challenged in planning activities and lead the process to manage and implement the activities. Participants must be creative to plan for interactive activities so that other participants would benefit from them. It involves decision making and practical communication skills as some youth must be a leader to delegate tasks to the committee. Youth also need to manage the activities with the program administrator to book and arrange slots and perhaps some equipment. At this stage, youth need to be multi-skills and actively communicate with other persons. Lerner (2004), in his study, pointed out that programs that incorporate positive and consistent adult-youth contacts, skill-building activities, and opportunities for leadership participation in community-based activities are the most likely to develop 5Cs (Lerner, 2004). Moreover, Lerner and his colleagues established 5Cs as five crucial markers of PYD, which stood for Competence, Confidence, Connection, Character, and Caring (Lerner et al., 2005). The reinforcement of 5Cs is directly affected by developing the two fundamental components of positive youth development: individual assets and ecological assets (Lerner et al., 2013).

Two main assets need to be developed first, namely, individual assets and ecological assets that lead to the formation of 5Cs (Lerner et al., 2005; Lerner et al., 2010; Agans et al., 2013). In terms of participation in international exchange programs, the participating youth have passed several stages of assessment that determine them as eligible participating youth who possess adequate knowledge, skills, and other competencies. These individual assets are the strengths in youth that encompass the cognitive, emotional, and behavioural strengths. Benson et al (2007) further explained that individual assets in PYD are youth's skills, competencies, and values that can be developed through a dedication to learning, values, social intelligence, and sound identity.

The ecological assets are accessed for youth to acquire life skills, build and maintain relationships (Agans et al., 2013). As for the international exchange programs, ecological assets refer to the environment of the programs themselves. In other words, ecological assets are the nature of the programs, which provides diverse skill-building and horizon-widening opportunities among participating youth. Furthermore, ecological assets play an important role as a complement to individual assets, whereby the combination of both makes the participating youth as individuals who developed positively. That can increase participating youths' 5 Cs through the relationship between individuals and context (Lerner et al., 2013).

Besides that, the IYEX programs also enable youth to achieve the 6th C - contribution. It can happen through the Post-Program Activities (PPA) that are compulsory to be fulfilled after return to their respective countries. PPA is one of the activities in the international exchange programs. It requires participating youth to plan dan execute specific projects in home countries which would benefit the communities. It implies that these activities can cultivate the nature of serving back to the community among the participating youth and directly affect the positive contribution to self, family, and community (Lerner et al., 2010). 


\section{Conclusion}

The PYD has a wide range of interpretations. It is a part of the field of adolescence that is inclusive and active. There is not a "one-size-fits-all" solution. The current study reveals that there are many areas in IYEX programs that contribute to PYD. The study also demonstrates the value of taking a strengths-based approach to adolescent development while working with diverse youth and determining the individual and ecological assets related to PYD in various areas. In other words, everyone's strengths will likely be very different, and it may take some effort to figure out what those are. Whatever their strengths and context, the goal is to identify, leverage, and enhance those strengths accordingly to achieve the 5Cs of PYD.

\section{References}

Agans, J. P., Champine, R. B., DeSouza, L. M., Mueller, M. K., Johnson, S. K., \& Lerner, R. M. (2013). Activity Involvement as an Ecological Asset: Profiles of Participation and Youth Outcomes. Journal of Youth Adolescence, 1-14. doi: 10.1007/s10964-014-0091-1.

Arshad, M. M., Ismail, I. A., Fesol, S. F., \& Ismail, A. (2021). Character development and youth leadership mentoring. Pertanika Journals of Social Science and Humanities, 39 - 55.

Arshad, M. M., Ismail, I. A., Suandi, T., \& Omar, Z. (2017). Linking Mentoring within a Community of Practice to Positive Youth Development among Participants of a Youth Leadership Program in Malaysia. International Journal of Academic Research in Business and Social Sciences, 7(8), 642-648. doi.org/10.6007/IJARBSS/v7-i8/3270.

Baber, K. M., \& Rainer, A. (2020). Positive Youth Development: Bridging Theory into Practice at Therapeutic Schools and Programs. Journal of Theoretical Social Psychology, 46-62.

Baharun, R., Awang, Z., \& Padlee, S. F. (2011). International students choice criteria for selection of higher learning in Malaysian private universities. African Journal of Business Management, 5(12), 4704 -4714. doi: 10.5897/AJBM10.422.

Benson, P. L., Scales, P. C., Hamilton, S. F., \& Junior, A. S. (2007). Positive Youth Development: Theory, Research, and Applications. John Wiley \& Sons, Inc.

Bonell, C., Hinds, K., Dickson, K., Thomas, J., Fletcher, A., Murphy, S., . . Campbell, R. (2016). What is positive youth development and how might it reduce substance use and violence? A systematic review and synthesis of theoretical literature. BMC Public Health, 1-14.

Cabinet Office, Government of Japan. (2018). International Youth Exchange Report: The 45th Ship for Southeast Asian and Japanese Youth Program. Tokyo, Japan: Cabinet Office, Government of Japan.

Clubs, R. (2018). Rotary Youth Exchange Annual Report. Rotary Organization.

Council, N. H. (2021). What is 4-H? Retrieved June 17, 2021 from https://4-h.org/about/whatis-4-h/.

Damon, W. (2004). What is Positive Youth Development? The ANNALS of the American Academy of Political and Social Science, 13-24; doi:10.1177/0002716203260092.

Dotterweich, J. (2015). Positive Youth Development 101. Cornell University.

Eccles, J., \& Gootman, J. A. (2002). Community programs to promote youth development / Committee on Community-Level. Washington D.C: National Academy Press.

Economic Planning Unit. (2015). Eleventh Malaysia Plan 2016-2020 Anchoring Growth on People. WP Putrajaya: Economic Planning Unit, Prime Minister's Department. 
Enfield, R. P. (2001). Connections between 4-H and John Dewey's philosophy of education. 4H Center for Youth Development. 4-H Center for Youth Development. .

Fitzsimmons, S. R., Flanagan, D. J., \& Wang, X. A. (2013). Business Students' Choice of ShortTerm or Long-Term Study Abroad Opportunities. Journal of Teaching in International Business, 125-137. https://www.tandfonline.com/doi/abs/10.1080/08975930.2013.819710.

Gabowski, S., Wearing, S., Lyons, K., \& Landon, M. T. (2017). A rite of passage? Exploring youth transformation and global citizenry in the study abroad experience. Tourism Recreation Research, 1-11. https://dx.doi.org/10.1080/02508281.2017.1292177.

Geldhof, G. J., Bowers, E. P., \& Lerner, R. M. (2013). Special Section Introduction: Thriving in Context: Findings from the 4-H Study of Positive Youth Development. Journal of Youth Adolescence, 42, 1-5. doi: 10.1007/s10964-012-9855-7.

Gorman, D. M. (1995). The effectiveness of DARE and other drug use prevention programs. American Journal of Public Health, 85(6), 873-874.

Hamzah, A. (2005). Helping Malaysian Youth Move Forward: Unleashing The Prime Enablers. Serdang, Selangor: Corporate Communication Department, Universiti Putra Malaysia, Serdang, Selangor.

Institute for Youth Research Malaysia. (2018). Kajian Pembangunan Belia Positif (8C) di Malaysia. WP Putrajaya: Ministry of Youth and Sports.

Institute for Youth Research Malaysia, I., \& Universiti Putra Malaysia, U. (2015). Kajian Kesejahteraan Hidup Belia. WP Putrajaya: Ministry of Youth and Sports.

Interagency Working Group on Youth Programs. (2021). Positive youth development. Retrieved from https://youth.gov/youth-topics/positive-youth-development

Kabanbayeva, G., Gureva, M., Bielik, P., \& Ostasz, G. (2019). Academic mobility and financial stability: A case of Erasmus student exchange programs. Journal of International Studies, 12(1) 324-337. doi:10.14254/2071-8330.2019/12-1/22.

Kim, S. S., Chen, W., Kolodziej, M., Wang, X., Wang, V. J., \& Ziedonis, D. (2016). A systematic review of smoking cessation intervention studies in China. Nicotine \& Tobacco Research, 891-899. https://doi.org/10.1093/ntr/ntr289.

Lai, E. S., Kwok, C.-L., Wong, P. W., Fu, K.-W., Law, Y.-W., \& Yip, P. S. (2016). The effectiveness and sustainability of a universal school-based programme for preventing depressionin Chinese adolescents: A follow-up study using quais-experimental design. PloS One, https://doi.org/10.1371/journal.pone.0149854.

Lerner, R. M. (2017). Commentary-Studying and Testing the Positive Youth Development Model: A Tale of Two Approaches. Child Development, 88(4), 1183-1185. doi:10.1111/cdev.12875.

Lerner, R. M., Almerigi, J. B., Theokas, C., \& Lerner, J. V. (2005). Positive Youth Development A View of the Issues. Journal of Early Adolescence, 25(1), 10-16. doi: 10.1177/0272431604273211.

Lerner, R. M., Eye, A. V., Lerner, J. V., Lewin-Bizan, S., \& Bowers, E. P. (2010). Special Issue Introduction: The Meaning and Measurement of Thriving: A View of the Issues. Journal of Youth and Adolescence, 39(7), 707-719. doi: 10.1007/s10964-010-9531-8.

Lerner, R. M., Lerner, J. V., Almerigi, J. B., Theokas, C., Phelps, E., Gestsdottir, S., . . B, D. L. (2005). Positive Youth Development, Participation in Community Youth Development 
Programs, and Community Contributions of Fifth-Grade AdolescentsFindings From the First Wave Of the 4-H Study of Positive Youth Development. The Journal of Early Adolescence, 25(1), 17-71.

Lerner, R. M., Lerner, J. V., Bowers, E. P., \& Gedholf, G. J. (2015). Positive Youth Development and Relational-Developmental-Systems. Handbook of Child Psychology and Developmental Science, 7th Edition, 607-651. John Wiley and Sons Inc.

Lerner, R. M., Lerner, J. V., Lewin-Bizan, S., Bowers, E. P., Boyd, M. J., Mueller, M. K., \& Napolitano, C. M. (2011). Positive Youth Development: Processes, Programs, and Problematics. Journal of Youth Development, 6(3), 40-64.

Lerner, R. M., Lerner, J. V., Lewin-Bizan, S., Bowers, E. P., Boyd, M. J., Mueller, M. K., . . . Napolitano, C. M. ( 2011). Positive Youth Development: Processes, Programs, and Problematics . Journal of Youth Development, 6(3), 1-25.

Lerner, R. M., Napolitano, C. M., Boyd, M. J., Mueller, M. K., \& Callina, K. S. (2013). Mentoring and positive youth development; Handbook of youth mentoring; 2nd Ed., 17-27. SAGE Publications, Inc.

Lerner, Richard M. (2004). Liberty: Thriving and civic engagement among America's youth. Thousand Oaks, CA: Sage.

Lerner, R. M. (2005). Promoting Positive Youth Development: Theoretical and Empirical Bases. Paper Presented at the White Paper Prepared for Workshop on the Science of Adolescent Health and Development, National Research Council, Washington, DC.

Logwood, S., \& Thomas, B. (2017). Positive Youth Development. Ohio University.

Lopez, A., Yoder, J. R., Brisson, D., Lechuga-Pena, S., \& Jenson, J. M. (2015). Development and validation of a Positive Youth Development measure: The Bridge-PYD. Research on Social Work Practice, 726-736.

Maclean, R., \& Adamson, B. (2016). Education in the Asia-Pacific Region: Issues, Concerns and Prospects. Springer.

Mahoney, J. L., Vandell, D. L., Simpkins, S., \& Zarrett, N. (2009). Adolescent Out - of - School Activities. Handbook of Adolescent Psychology, 228-269. doi:10.1002/9780470479193.adlpsy002008 .

Malaysia, I. F. (2015). Malaysian Youth Asset Wellbeing Development Study . WP Putrajaya: Institute for Youth Research Malaysia.

Malaysian Qualifications Agency. (2021). Code of Ethics of the MQA Appointment Panel. https://www.mqa.gov.my/pv4/document/2021/KOD\%20ETIKA\%20PANEL\%20LANTI KAN\%20MQA.pdf.

Maximova, S., Omelchenko, D., Noyanzina, O., \& Maksimov, M. (2018). Youth exchange programs in the SCO countries and their integrative potential: Russia's vantage point. International Conference on Advanced Studies in Social Sciences and Humanities in the Post-Soviet Era (ICPSE 2018), 1-10. EDP Sciences https://doi.org/10.1051/shsconf/20185503035.

Mclver, D., Lengnick-Hall, C. A., Lengnick-Hall, M. L., \& Ramachandran, I. (2012). Integrating knowledge and knowing: A framework for understanding knowledge-in-practice. Human Resource Management Review, 86-99. https://doi.org/10.1016/j.hrmr.2011.11.003. 
Ministry of Youth and Sports. (2015). Malaysian Youth Policy, MYP. WP Putrajaya: Ministry of Youth and Sports.

Ministry of Youth and Sports. (2016). Ministry of Youth and Sports Strategic Plan 2016-2020. WP Putrajaya: Ministry of Youth and Sports.

Mueller, M. K., Phelps, E., Bowers, E. P., Agans, J. P., Urban, J. B., \& Lerner, R. M. (2011). Youth development program participation and intentional self-regulation skills: Contextual and individual bases of pathways to positive youth development. Journal of Adolescence, 1115-1125. doi:10.1016/j.adolescence.2011.07.010.

Overton, W. F. (2015). Processes, relations, and relational-developmental-systems. Handbook of child psychology and developmental science, 9-62.

Overton, W. F., \& Mueller, U. (2012). Meta-theories, theories, and concepts in the study of development. Handbook of Psychology, 19-58.

Phelps, E. A. S. Z., Warren, A., Jeličić, H., Eye, A. V., \& Lerner, R. M. (2009). The structure and developmental course of Positive Youth Development (PYD) in early adolescence: Implications for theory and practice. Journal of Applied Developmental Psychology, 571-584. doi:10.1016/j.appdev.2009.06.003.

Piers, E. V., Harris, D. B., \& Herzberg, D. S. (2018). Piers-Harris Children's Self-Concept Scale (Piers-Harris 3) 3rd Ed. CA: Western Psychological Services.

Qi, S., Hua, F., Zhou, Z., \& Shek, D. T. (2021). Trends of positive youth development publications (1995-2020): A scientometric review. Applied Research in Quality of Life, 1-26.

Qi, Shaojie; Hua, Fengrui; Zhou, Zheng; Shek, Daniel T. L. (2021). Trends of Positive Youth Development Publications (1995-2020): A Scientometric Review. Applied Research in Quality of Life, 1-26. https://doi.org/10.1007/s11482-020-09878-3.

Radhakrishna, R. B., \& Ingram, P. D. (2005). Experiences of 4-H Japanese Exchange Program on Participants: An Evaluative Study. Journal of Extension, 43(3), 1-7.

Rawee, A. H. (2016). Indeks Belia Malaysia: Gambaran Impak Pelaksanaan Dasar Belia Malaysia. Malaysian Journal of Youth Studies, 15, 9-15.

Roberts, N., Butcher, L., Bowers, P., Jarrett, T., Foster, D., Powell, T., . . Apostolova, V. (2016). UK Youth Parliament Briefing 2016. United Kingdom: House of Common Library.

Roth, J. L., \& Brooks-Gunn, J. (2003). What Exactly Is a Youth Development Program? Answers From Research and Practice. Applied Developmental Science, 7(2), 94-111. doi.org/10.1207/S1532480XADS0702_6.

Sani, M. U., \& Saad, S. (2018). Perlaksanaan dan Cabaran Penglibatan Belia dalam Parlimen Belia Malaysia. Journal of Social Sciences and Humanities, 13(1), 1-17. ISSN: 1823$884 x$.

Shek, D. T., Dou, D., Zhu, X., \& Chai, W. (2019). Positive youth development: current perspectives. Adolescent Health, Medicine and Therapeutics, 131-141. doi: 10.2147/AHMT.S179946.

Shek, D. T., Dou, D., Zhu, X., \& Chai, W. (2019). Positive youth development: current perspectives. Adolescent Health, Medicine and Therapeutics, 131-141. https://doi: 10.2147/AHMT.S179946.

Silbereisen, R. K., \& Lerner, R. M. (2007). Approaches to Positive Youth Development. Thousand Oaks, California: SAGE Publications, Inc. 
Tangen, D., Henderson, D., Alford, J., Hepple, E., Alwi, A., \& Hassan Shaarib, Z. \&. (2017). Shaping Global Teacher Identity in a short-term Mobility Program. Asia-Pacific Journal of Teacher Education; 45(1), 23-38.

https://doi.org/10.1080/1359866X.2015.1119803.

Tsoukalas, I. (2019). Apprentice Cosmopolitans Social identity, community, and learning among ERASMUS exchange students. Academic dissertation for the Degree of Doctor of Philosophy in Social Anthropology at Stockholm University, ISSN 0347-0830.

Turnnidge, J., Cote, J., \& Handcock, D. J. (2014). Positive youth development from sport to life: explicit or implicit transfer? Quest, 203-217.

United Nations. (2012). United Nations youth Participation. Retrived June 15, 2021 from http://www.un.org/esa/socdev/documents/youth/fact-sheets/youth participation.pdf. United Nations.

Universiti Malaysia Sabah. (2021). Student Mobility Programme Guidelines (Local \& International).

https://pendaftar.ums.edu.my/pppg/images/Files/STUDENT_MOBILITY_GUIDELINES _PROGRAMME.pdf

World Assembly of Youth, W. (2015). Youth participation in decision making. WAY Reports; Retrieved June 14, 2021 from

"http://www.un.org/esa/secdev/documents/youth/fact-sheets/youth-politicalparticipation.pdf".

Youth Development Division. (2016). Malaysian Youth Parliament (PBM) Report. WP Putrajaya: National Youth and Sports Department.

Youth Development Division. (2018). International Youth Exchange Participant Program Selection Camp Report. WP Putrajaya: National Youth and Sports Department.

Youth Development Division. (2018). International Youth Exchange Participant Program Selection Camp Report. WP Putrajaya: National Youth and Sports Department.

Youth Development Division, N. Y. (2016). Perdana Fellow Program Report. WP Putrajaya: National Youth and Sports Department.

Zarrett, N., Fay, K., Li, Y., Carrano, J., Phelps, E., \& Lerner, R. M. (2009). More Than Child's Play: Variable- and Pattern-Centered Approaches for Examining Effects of Sports Participation on Youth Development. Developmental Psychology; American Psychological Association, 45(2), 368-382. doi: 10.1037/a0014577.

Zhou, Z., Shek, D. T., \& Zhu, X. (2020). The Importance of Positive Youth Development Attributes to Life Satisfaction and Hopelessness in Mainland Chinese Adolescents. Frontiers in Psychology, 1-18. https://doi: 10.3389/fpsyg.2020.553313.

Zulkefli, M. Y., \& Rabi, N. M. (2021). Exploring the Usage of Computer-Mediated Communication in Assisting Individual with Autism Spectrum Disorder to Communicate. Journal of Contemporary Islamic Communication \& Media, 126-143.

Zulkefli, M. Y., \& Zulkifli, F. (2021). Exploring the Competency of The Assessor in Selecting the Participants for the International Youth Exchange Program in Malaysia. International Conference on Communication, Management and Humanities 2021 (ICCOMAH 2) EProceeding (115-133). Nilai, Negeri Sembilan, Malaysia: Academic International Dialogue (AID) Conferencer. 